\title{
Foreign Direct Investment as an Important Source of External Development Financing: New Evidence in Turkey
}

\author{
Mohamed Isse Ibrahim (İstanbul Commerce University, Turkey)
}

\begin{abstract}
Foreign direct investment is a critical source of external instruments for financing development for Turkey, FDI can contribute to technology diffusion, Economic growth, Employment generation and Sustainable development. However; the Objective of this research is to examine whether foreign direct investment as an external source of financing effects economic growth in Turkey, based on time series data from 2003 to 2016 during the Erdoğan administration. This study employed Harrod-domar growth model using under OLS method. The paper considerate main variables foreign direct investment, Exchange rate and labor force. Based on empirically investigated the study confirmed that foreign direct investment and Labor force has a positive significant relationship to economic growth in Turkey while exchange rate has a negative significant relationship to economic growth in Turkey. So this paper recommends that movement of Turkey should promote policies encourage and creation of a good microeconomic and macroeconomic a friendly environment and utilization of the careful of loose monetary policy to economic performance.
\end{abstract}

\section{Introduction}

The level of investment in a country is one of the main sources of economic development and growth. However, in most developing economies, actual foreign investment falls short of the preferred volume necessary to cause a significant raise in gross domestic product growth, a lot of developing economies depend on investment to resolve several economic problems and crisis. A large number of economists agreed that foreign direct investment plays main role in the development process of every country either high income, middle income or low income. For example (Zhang, 2001), confirmed that FDI led economic growth but concluded that its benefits are contingent upon certain characteristics of the host country. According to world development indicators point out that gross domestic product has been increased in overall GDI from $\$ 312$ billion to $\$ 860$ billion from 2003 to 2015 , the average economic growth is increasing annually more than $6 \%$ until 2008 , privatization program also to reduce state involvement in banking, basic communication, industry and transport. Before 1980s foreign investment inflows in Turkey was weak because of policy of import substitution that used to productions of domestic via nontariffs barriers and tariffs, foreign investors were subject government control to strict. The number operating of firms with FDI in 1980 was 78, which increased to 6584 as 2003 . When the FDI amount is compared number of firms was approximately 3 million USD. The trend of foreign direct investment towards sectors has given risen, the share of service sector was $28.5 \%$ during 1990 to 1995 , has increased to $52.7 \%$ in the $1996-2002$ period. By the mentioned period the share of industrial sector was $56.7 \%$. The share of agricultural sector was $1.4 \%$ between 1990 and 2002 (Alıc1\& Ucal, 2003). Last two decade Turkish economy perceived a rapid growth especially foreign direct investment considered the most powerful in the international economic relations. FDI inflow in Turkey represented by multinational and transnational companies. However, Turkey helped economic reform After Turkey a severe financial crisis in 2001, political stability, European Union accession process and privatizations to attract new investments and the levels of FDI net inflows has increased $0.5 \%$ of GDP in 2003 to 2\% in 2015. Similarly, GDP growth increased from $5 \% 2003$ to $6 \% 2015$ (Sirin, 2017). The overall foreign direct investment of net inflow has been increased very significantly from $\$ 2.8$ billion to $\$ 18$ billion from 2003 to 2015 .The main purpose of the research is to measure foreign investment on Economic Growth in Turkey, the paper specifically considering some important variables like foreign direct investment, labor force and exchange rate. The findings very interesting to policy makers and central banks in Turkey and developing economics because could be same case of other developing economics suggest should consider the level of effect of the foreign direct investment on economic growth. The rest of the research comprised as follows: section two discusses the empirical and theoretical literature on the foreign direct investment and economic growth. Section three describes data used and the methodology. Section four presents the empirical results and discusses of the finding. Section five offers managerial and policy implication and concluding remarks.

\section{Literature Review}

Several literates have been conducted the relationship among Economic growth and foreign direct investment in the literature. The studies rage forms a specific country to cross countries using different data source and type. The findings of individual studies were different which depends on Data, Period selected, model of the studies and also used various proxies for foreign direct investment and different methodologies. The study on cross countries analysis were done Alvarado, Ponce, \& Ponce, (2017) carried out the impact of foreign investment on economic growth in Latin American countries, the study used paned data from 1980 to 2014, the finding of the study based the development level reached by the countries, Foreign direct investment in lower middle counties is negative 
significant on economic growth, while upper middle income countries the is insignificant and uneven. Finally, FDI has a significant with positive effect on gross domestic product in high-income counties. The study suggested counties in medium low income of Latin American should promote fiscal instruments to attract foreign investors, as well as high income counties in the region can encourage foreign investment inflows to increase domestic production. Moreover Amin \& Khalid, (2014) conducted investigation the relationship between foreign direct investment and economic growth review of Literature over 1994-2012 period. The study reviewed 33 papers relating FDI and EG The finding reveals that most of the studies FDI that positive impact on the host country's productivity growth which mainly contributes well- development financial markets, Human capital, technology and open trade regimes. A few cases are negative or even null impact. Additionally Malikane \& Chitambara, (2017) examined the effect of foreign direct investment, technology and economic productivity in 45 African countries, the study used panel date over period 1980-2012, they applied the two-step systems GMM method and the fixedeffects to account for the issues of endogeneity. The result of the study revealed that generally weak but positive effect of foreign direct investment on total productivity growth because of the failure by many African counties to fully adopted foreign capital may cause the limited absorptive capacity. The paper stated that huge gap of technology is lead to catch-up and greater diffusion of knowledge, so the study suggested that African countries need to improve strengthen their institution to expend the capacity and close gap of the technology. Iamsiraroj, (2015) investigated the relationship between foreign investment and Economic growth nexus 124 cross country, the date over 1971-2010 period. The paper was applied simultaneous system of equations approach. The finding shows that foreign direct investment is highly associated with productivity of countries and vice versa, as well as the study stated trade openness, labor force and freedom of economic are keys determinants of foreign direct investment, the result indicate that consistently in favor of important gains to host countries from attract foreign direct investment inflow. Based results, the authors put forward of recommended that host counties should promote policy on attracting FDI to enhance productivity of country as well as to minimalize the volatility of total productivity. Maeseneire \& Claeys, (2012) carried out the investigation the relationship medium and small sized enterprises, FDI, and financial constraints in Belgium. The authors interviewed thirty-two Belgian medium and small sized enterprises five of them are banks and five venture capitalists. The found reported there is finance gab hinder development of small firms, leads to suboptimal and foreign investment hosting country development. Under the result of the paper the study suggested policy and recommendation to consider the barriers faced SMEs, Belgium government must make sure that restrictions the lending, investor, bankruptcy procedures and creditor protection. As an illustration, India and China have been largest recipient of foreign direct investment since 1990s. Kim, Lin, \& Suen, (2013) have assessed the impact of foreign direct investment and trade openness on Investment depend upon social capacity matters, the paper used cross-sectional data from 85 countries 1975 up to 2010 , applied regression analysis approach. The researchers have found that trade openness has positive effect on domestic investment when social capability such as political institutions, financial development and human capital have good performance a negative effect in countries with opposite attributes, while foreign direct investment has a positive impact domestic investment when social capability of countries have bad performance but positive effect with opposite attributes. The study suggested FDI is beneficial for domestic investment so low income counties should promote trade openness to attract foreign direct investment. As far as the effect of foreign direct investment on productivity growth Feeny, Iamsiraroj, \& Mcgillivray, (2014) have investigated role foreign direct investment on domestic production growth in 209 pacific island countriesfrom1971 to 2010, the result indicates that the FDI has positive associated with higher productivity growth in host pacific countries, on the other hand pacific region has given more positive assessments of aid and remittance because of poverty of the region, limit resource and small domestic market. Based on the result two policy: first movements in island find ways of increase the impact of foreign direct investment on economic growth, second movements should encourage firms from developed countries to invest the pacific region. Additionally Tahir, Khan, \& Shah, (2015) examined the effect external factors on productivity growth in Pakistan for period 1977 to 2013, the study applied ARDL approach to co-integration. The result of the study reveals remittance and foreign investment has positive associated and improve long run productivity growth in Pakistan economy while foreign import has negative effect one economic growth (Munemo, 2016). examine link between foreign direct investment and start-up of business depends upon financial market development for the panel of 92 developing economics for the period 2004 to 2012. The result reveals that foreign direct investment appears has effect on business start-ups with high level development of financial in the host economy, finally the paper suggested host counties should improve financial market will facilitate higher growth of capita income and important for encourage entrepreneurship. furthermore Makiela \& Ouattara, (2018) explored the impact of foreign direct investment on productivity growth in developed and developing countries for the period 1970 to 2007 . The empirical result of the study shows that in developing countries foreign direct investment has statistically significant with positive impact on productivity growth. Finally Sunde, (2017) empirically investigated the effect foreign direct investment on productivity growth in South Africa for the period 1990 up to 2014. The paper applied the autoregressive distributed model and VECM granger causality. The paper indicates foreign investment and export does not cause productivity growth in South Africa but the study confirmed that foreign investment led economic growth for South Africa. at the theoretical level is has been argued link between foreign direct investment and productivity growth, these recent studies have provided different influences of FDI 
on economic growth but all these confirmed FDI has beneficial the economy host country. Therefore this paper investigates foreign direct investment as an important source of external factor of development in Turkey.

\section{Data and Methodology}

\subsection{Harrod-Domar Growth Model}

Horrod-Domar clarified that equilibrium of economic growth is dictated by yearly investment returns and product of saving ratios. This implies economic growth will continue at rate of which society can mobilize saving of domestic resources combined with the production of investment. Realizing that the significant imperative with respect to developing countries is the capital shortage. Horrod-Domar Model explained the extension of open where investment can be financed both the flow foreign capital and Domestic. The model independently was developed by Roy Horrod in 1939 and Evsey Domar in 1996.

\subsection{Data}

The study uses the annual data economic growth and investment Time series during the Erdoğan administration from 2003 to 2016, obtained from World Bank. Gross domestic product is Nominal GDP at current price is GDP at price during a specified period. Official exchange rate is computed as an annual average based on monthly average of exchange rate determined by National Authorities. Foreign direct investment refers the net inflow of investment and components of the foreign direct investment are reinvested earning, equity capital and other capital. And Total labor force is all people who labor of supply for the production of services and good a certain period of time.

\subsection{Model Specification}

The study used OLS regression to estimate foreign direct effects on economic growth in Turkey. This article follows Harrod-Domar Growth Model:

$$
\mathrm{GDP}=\beta_{\mathrm{t}}+\beta_{1} \mathrm{FDI}_{\mathrm{t}}+\beta_{2} \mathrm{E}_{\mathrm{t}}+\beta_{4} \mathrm{~L}_{\mathrm{t}}+\varepsilon_{\mathrm{t}}
$$

Where GDP stands gross Domestic product, FDI is foreign direct investment inflow, E is official exchange rate, $\mathrm{L}$ is total labor force and $\varepsilon t$ is error term.

\section{Result and Discussion}

This study employed yearly data of Turkey, namely gross domestic product, foreign direct investment, Exchange rate and labor force. The statistical technique in used in this study is regression analysis using a time series data covering the period from 2003-2016 obtained from World Bank statistical report. First, the study use Summary Statistics and unit root test, to insure that the regression result would not be spurious. Second, the study uses correlation analysis to examine the relationship among the variables.

\subsection{Descriptive Statistics}

Present Summary Statistics which reveals that the stander deviation and mean.

\begin{tabular}{lclccc}
\hline Variable & Abr & Measurement & Obs & Mean & St. dev. \\
\hline Economic growth & GDP & Gross national product & 14 & 710000000000 & 202000000000 \\
$\begin{array}{l}\text { Foreign direct } \\
\text { investment }\end{array}$ & FDI & $\begin{array}{l}\text { Foreign direct } \\
\text { investment }\end{array}$ & 14 & 13000000000 & 6150000000 \\
$\begin{array}{l}\text { Labor force } \\
\text { Exchange rate }\end{array}$ & L & Total labor force & 14 & 25263778 & 3076695 \\
\hline
\end{tabular}

Table1. Summary Statistics of the Variables,

The result of descriptive statistics show that economic growth has the highest number of average while exchange rate has the lowest number of average mean as well as the standard deviation. 


\subsection{Correlation}

\begin{tabular}{llllll}
\hline & GDP & FDI & ER & L & TB \\
\hline GDP & 1 & & & & \\
EDI & $0.54 * *$ & 1 & & \\
ER & $0.57 * *$ & $0.12^{*}$ & 1 & 1 & \\
\hline
\end{tabular}

Note. $*$ indicates weak correlation, $* *$ indicates moderate correlation and $* * *$ indicates strong correlation

Table 2. Multicollinearity (Correlation Matrix)

It is evident from the correlation matrices of Table 2 reveals exchange rate and labor have the highest coefficient of the correlation is0.91, whereas foreign direct investment and exchange rate have The lowest coefficient of the correlation is 0.12 . All of the indicators have positive and weak relationship with dependent variable.

\subsection{Unit Root Test}

To test the data stationary is checked through Phillips-Perron and Augmented Dickey Fuller test are applied to trend and intercept. The results have showed that some variables are stationary at level while other non-stationary. However all variables became stationary at first difference, so all null hypotheses were not fail to rejected for every test at first difference.

\begin{tabular}{|c|c|c|c|c|c|}
\hline & Levels & $\begin{array}{l}\text { ADF } \\
\text { t-statistics }\end{array}$ & Prob. * & $\begin{array}{l}\text { PP } \\
\text { Adj. S-stat }\end{array}$ & Prob. * \\
\hline \multirow[t]{2}{*}{ GDP } & At Level & -1.394935 & -1.394935 & -0.724470 & 0.9462 \\
\hline & $1^{\text {st }}$ Difference & -4.193404 & 0.0316 & -7.903820 & 0.0003 \\
\hline \multirow[t]{2}{*}{ FDI } & At Level & -3.798013 & 0.0560 & -2.299713 & 0.4058 \\
\hline & $1^{\text {st }}$ Difference & -2.635106 & 0.2741 & -2.526040 & 0.3127 \\
\hline \multirow[t]{2}{*}{ ER } & At Level & 1.759423 & 0.9999 & 2.600927 & 1.0000 \\
\hline & $1^{\text {st }}$ Difference & -4.148955 & 0.0337 & -5.852614 & 0.0032 \\
\hline \multirow[t]{2}{*}{$\mathrm{L}$} & At Level & -2.352484 & 0.3822 & -4.518914 & 0.0174 \\
\hline & $1^{\text {st }}$ Difference & -3.238008 & 0.1241 & -3.238008 & 0.1241 \\
\hline
\end{tabular}

Table 3. Unit Root Test (Stationary Test at Level and at In Difference)

4.4 Estimation of the Model

\begin{tabular}{lllll}
\hline Dependent Variable: GDP & & & \\
\hline Variable & Coefficient & Std. Error & t-Statistic & Prob. \\
FDI & 8.426910 & 1.245585 & 6.765421 & 0.0000 \\
ER & $-3.81 \mathrm{E}+11$ & $3.39 \mathrm{E}+10$ & -11.21488 & 0.0000 \\
L & 111215.4 & 6023.334 & 18.46409 & 0.0000 \\
C & $-1.54 \mathrm{E}+12$ & $9.64 \mathrm{E}+10$ & -15.96717 & 0.0000 \\
R-squared & 0.987173 & Durbin-Watson stat & 2.288964 \\
\hline
\end{tabular}

Table 4. Regression Test

The result of the model shows that that FDI and labor force have positive effect and significant effect on economic growth in Turkey, exchange rate has negative and significant relationship to economic performance of Turkey. Furthermore, the study explains the foreign direct investment of Turkey has a positive relationship Productivity growth, this means that foreign investment has an important contribution in increasing the production level in country in the period 2003-2016. Investments play important role overall growth rate in Turkey economy because foreign inventors create new jobs, also well-develops markets of financials and the opens trade play important role in the production of the country and investment seems to great benefit economic growth rate most in the Electricity, Manufacturing, Wholesale and Retail Trade sectors and Gas and water. Exchange rate associates inversely rate to productivity of Turkey this implies asymmetric impact of the currency depreciation and appreciation on economic performance Turkey. The appreciation of exchange rate persuades that producer's losses of competitiveness and depreciation of Turkish currency increases the cost imports and discourage the foreign investors have an important role increasing the overall production levels. As the result indicates Labor force has positive impact to economic growth in Turkey this implies that increases labor productivity and skilled labors that will attract of foreign investors and creates economic stability.

\subsection{Model Stability}

The model stability is tested through CUSUM line. The following figure are obtained 


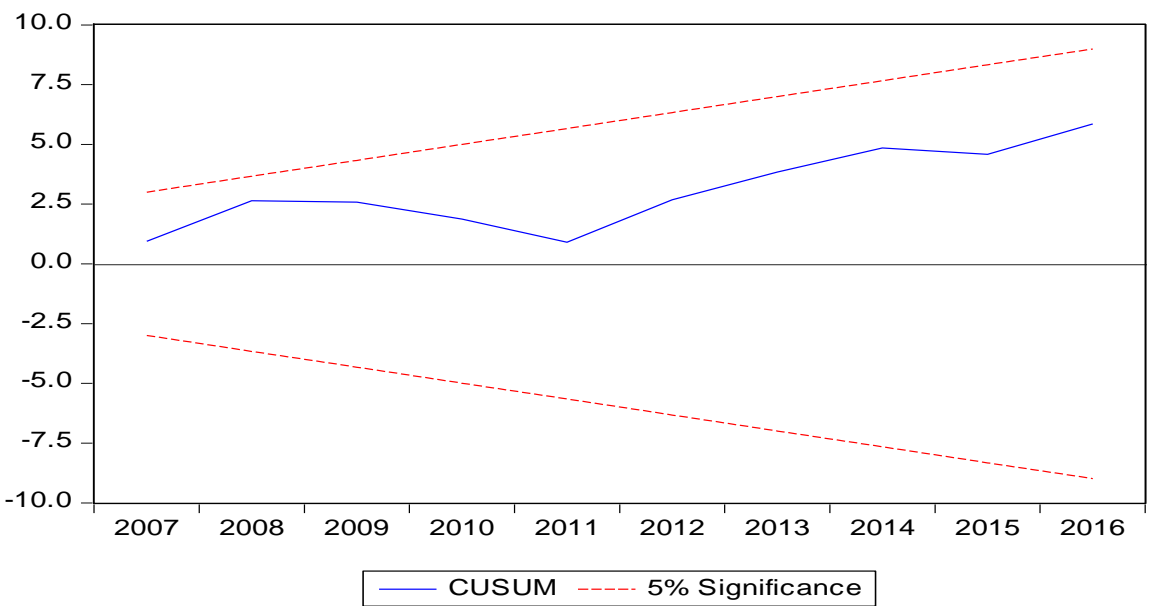

Figure 1. Cusum Line

The result of graph reveals that line of estimated is well within the 5 percent significant level, the model of estimated are stable and reliable.

\begin{tabular}{lll}
\hline Heteroskedasticity & Obs*R-squared 0.837912 & Prob. Chi-Square 0.3600 \\
serial correlation & Obs*R-squared 1.283447 & Prob. Chi-Square 0.5264 \\
Ramsey & T-statistic 0.780134 & Probability 0.4553 \\
Normality & Jarque-Bera 0.86 &
\end{tabular}

\section{Table 5. Diagnostic Checking}

The report of diagnostic checking reveals that the model is free form autocorrelation nor Heteroskedasticity which means the two tests are insignificants at significant level at 5 percent. Moreover Ramsey test and Normality reveal that are correct and the distributed is normal. Therefore model of choosing is best fit since DW is 2.28 and $\mathrm{R}$ square is $98 \%$.

\section{Conclusion and Policy Recommendations}

The paper empirically examined foreign direct investment as an external source of financing effects on economic growth in Turkey based on time series date from 2003 to 2016. The article applied Harrod-Domar Growth Model using MRA under the regression method, known as the OLS bounds testing approach to effect of foreign direct investment on economic growth. The Summary Statistics and unit root was tested to examine the existence of which could make the regression result spurious and Correlation approach was used to emanate the relationship among the variables. The findings confirmed foreign direct investment and labor force has a positive impact to economic growth in Turkey, this implies both contribute rate growth overall positive in Turkish economy and foreign direct investment and labor force spur economic growth. The OLS method found Exchange rate has a negative impact to productivity of Turkey this indicates the fluctuation Turkish currency may discourage the foreign investors play an important role in increasing production levels.

Based on the empirical result in this research and father to induce economic performance in Turkey. There is need for the government retain policies in order to accelerate the attraction of foreign inventories following policies are suggested: the Turkey government should encourage foreign direct investment through macroeconomic and microeconomic a friendly environment and utilization of the careful of loos monetary policy to economic performance. Central Bank of the Republic of Turkey should have important role to control volatility of exchange rate in a way that is prevented rising inflation without affecting productivity and investment adversely. We hope that this article will promote additional research on investigating the foreign direct investment as external source of financing effects on economic growth in Turkey. It should be very interesting to finding the relationship between foreign direct investment and economic performance in Turkey. Therefore, our results may need further analysis and additional empirical result by contributing economic performance and updated in Turkey.

\section{References}

- Alıcı, A. A., \& Ucal, M. Ş. (2003). "Foreign Direct Investment, Exports And Output Growth Of Turkey : Causality Analysis". In European Trade Study Group (ETSG) Fifth Annual Conference.

- $\quad$ Alvarado, R., Ponce, P., \& Ponce, P. (2017). "Foreign direct investment and economic growth in Latin America". Economic Analysis and Policy. https://doi.org/10.1016/j.eap.2017.09.006 
- Amin, M., \& Khalid, M. (2014). "Foreign Direct Investment and Economic Growth "Literature Review from 1994 to 2012. Procedia - Social and Behavioral Sciences, 129, 206-213. https://doi.org/10.1016/j.sbspro.2014.03.668

- $\quad$ Feeny, S., Iamsiraroj, S., \& Mcgillivray, M. (2014). "Growth and Foreign Direct Investment in the Paci fi c Island countries". Economic Modelling, 37, 332-339. https://doi.org/10.1016/j.econmod.2013.11.018

- Iamsiraroj, S. (2015). "The Foreign Direct Investment-Economic Growth Nexus". International Review of Economics and Finance. https://doi.org/10.1016/j.iref.2015.10.044

- $\quad$ Kim, D., Lin, S., \& Suen, Y. (2013). "Investment, trade openness and foreign direct investment : Social capability matters". International Review of Economics and Finance, 26, 56-69. https://doi.org/10.1016/j.iref.2012.08.008

- Maeseneire, W. De, \& Claeys, T. (2012). SMEs, "foreign direct investment and financial constraints : The case of Belgium". International Business Review, 21(3), 408-424. https://doi.org/10.1016/j.ibusrev.2011.03.004

- $\quad$ Makiela, K., \& Ouattara, B. (2018). "Foreign direct investment and economic growth : Exploring the transmission channels". Economic Modelling, (July 2017), 1-10. https://doi.org/10.1016/j.econmod.2018.02.007

- $\quad$ Malikane, C., \& Chitambara, P. (2017). "ScienceDirect Foreign direct investment ( FDI ), productivity and the technology gap in African economies". Journal of African Trade. https://doi.org/10.1016/j.joat.2017.11.001

- Munemo, J. (2016). "Foreign Direct Investment and Business Start-up in Developing Countries: The Role of Financial Market Development". Quarterly Review of Economics and Finance. https://doi.org/10.1016/j.qref.2016.08.010

- $\quad$ Sirin, S. M. (2017). "Foreign direct investments ( FDIs ) in Turkish power sector : A discussion on investments , opportunities and risks". Renewable and Sustainable Energy Reviews, 78(September 2016), 1367-1377A. https://doi.org/10.1016/j.rser.2017.05.160

- Sunde, T. (2017). "Foreign direct investment and economic growth: ADRL and causality analysis for South Africa". Research in International Business and Finance, 1-23. https://doi.org/10.1016/j.ribaf.2017.04.035

- $\quad$ Tahir, M., Khan, I., \& Shah, A. M. (2015). "Foreign Remittances , Foreign Direct Investment, Foreign Imports and Economic Growth in Pakistan" : A Time Series Analysis. Arab Economics and Business Journal, 10(2), 82-89. https://doi.org/10.1016/j.aebj.2015.06.001

- Zhang. (2001). "Does Foreign Direct Investment Promote Economic Growth? Evidence from East Asia and Latin America". Contemporary Economic Policy, 19(2), 175-185. https://doi.org/10.1111/j.14657287.2001.tb00059.x 